\title{
The Representation of Ireland in Bertalan Szemere's Utazás külföldön or A Journey Abroad
} A Study of Szemere's Image-Forming Sources

\author{
Márta PINTÉR \\ University of Pannonia (Veszprém, Hungary) \\ English and American Studies Institute \\ pinterm@almos.uni-pannon.hu
}

\begin{abstract}
The present study adds to my ongoing research into Irish-Hungarian relations in the nineteenth century. As such it is concerned with Bertalan Szemere's representation of Ireland in his travelogue Utazás külföldön [A Journey Abroad]. It approaches Szemere's work from the perspective of the following three questions. How does Szemere's trip to Ireland fit into the tradition of Irish-Hungarian contacts? What urged Szemere to sail over to Ireland and extend his already long and tiring tour of Europe? And finally, what factors shaped Szemere's image of Ireland in his travel account? A preliminary study of the conditions of Szemere's trip and his actual account of the country has led me to the hypothesis that in the process of creating his own representation of Ireland Szemere heavily relied on external sources. I seek to answer these questions by identifying the place of Szemere's travel account in the tradition of Hungarian-Irish contacts; by relating it to other texts on Ireland by Szemere's Hungarian contemporaries; and by comparing it to particular reports on Ireland by European travellers. My aim is to prove that Szemere's representation of Ireland was primarily informed and moulded by German and English sources as they were transferred to Szemere by some Hungarian periodicals. My study also emphasizes the importance of further research into the interaction of Hungarian and European discourse on Ireland in the nineteenth century.
\end{abstract}

Keywords: Hungarian-Irish contacts, the Age of Reforms, reformist travellers, German and English intermediaries.

\section{Introduction}

In Dublin (4 August, 1837) first I climbed Nelson's 186-foot commemorative column [...]; The city is big but it will not impress one as great, it is clean but 
poverty makes it look disgusting, and it evokes the image of a canal in ancient Rome which is made of marble but overflows with sewage. Yet, I was still satisfied at the "top." But I descended and I was incapable of enjoying the view any more. I felt overwhelmed by the sight of destitution and suffering all around me - awful misery nowhere ever seen before. (Szemere 1983, $353-354)^{1}$

The passage above is the English translation of a Hungarian description of the city of Dublin included in Bertalan Szemere's travelogue entitled Utazás külföldön or A Journey Abroad. A writer and a prestigious public figure, Szemere belonged to the so-called Young Hungary Movement, a group of reformist politicians in the Age of Reforms (1825-1848), which preceded Hungary's abortive struggle for independence from the Habsburg Monarchy in 1848-49. As a leading politician of the party opposing Habsburg rule Szemere also served as Prime Minister in Hungary's first, short-lived responsible government in 1849.

During the reform years, in 1836 and 1837 Szemere went on a Western European study trip, and visited "Germanland," France, the Czech country, Great Britain and "Irishland," the Netherlands, Belgium, the Rhineland, Switzerland and Bavaria. He stopped at several developed Western cities, such as Berlin, Amsterdam and Paris, where he stayed for nearly a half year. In Britain he spent a whole month in London, and extended his tour to as far in the north as Liverpool, Newcastle and even Glasgow. The entire tour lasted for almost a year and a half. Throughout the tour Szemere recorded his impressions and experiences, expanded them into a travelogue, which he published as Utazás külföldön or A Journey Abroad. Although censorship delayed the release of the printed book until 1840, in just nine months it was sold in a thousand and two hundred copies. Reflecting on its wide popularity, Antal Csengery, another leading reformist and Szemere's friend at the time, called the work "the schoolbook of Young Hungary" (qtd. in Csorba 1944, 47).

Extending my earlier research into nineteenth-century Irish-Hungarian contacts (Pintér 2012, 2013, 2015), in this study I focus on Szemere's account of his visit to Ireland from 4 to 8 August, 1837. I am fundamentally concerned with the following questions. How does Szemere's trip to Ireland fit into the tradition of Irish-Hungarian relations? What inspired and urged Szemere to sail over the Irish Sea, and lengthen his already long and tiring journey with a visit to the Emerald Island? And finally, what factors moulded and sourced the image that Szemere creates of Ireland in his own account?

With regard to my third question it should be noted that although Szemere's trip to Ireland took altogether five days in effect it only meant a three-day stay in Dublin: on the first day he took the boat from England to Ireland, on the morning of the fifth day he was already sailing back to England, and as we know, he did not

1 The translations from Hungarian texts are my own throughout the article. 
travel extensively outside of the Irish capital. Therefore, it is worth recognizing that Szemere's account includes certain statements that presuppose a deeper and more thorough study of conditions in Ireland. For instance, in Dublin, he depicts a free kitchen which feeds some three thousand paupers daily (1983, 356-357). In connection with the countryside, which he did not actually tour, Szemere states that the poor Irish live on potatoes, and grow the worst kind, the so-called “pig potatoes," because of its high yields (1983, 358). Viewing Szemere's wellinformed observations against the backdrop of his fleeting visit in the Irish capital I propose that his presentation of Ireland did not exclusively rely on his direct experience of the country but on some outer sources.

In seeking answers to these questions and attempting to prove the veracity of my hypothesis first I will examine Szemere's description of Ireland in the frame of Irish-Hungarian relations. Then I will explore how it relates to contemporaneous Hungarian and European discourse concerned with Ireland in the early-nineteenth century.

\section{Szemere and the Tradition of Irish-Hungarian Relations}

There is a wide range of primary and secondary texts, historical documents and modern scholarly works that provide evidence of a long line of Irish-Hungarian relations and of shared interest by the two peoples in each other's histories. The centuries-old tradition of mutual curiosity had yielded inter-country visits and related documents, and a knowledge of these may have aroused Szemere's desire to see the Emerald Island with his own eyes.

The first group of these documents dates back to the Late Middle Ages. The earliest extant references to a Hungarian in Ireland are about Lôrinc Tar, a Hungarian cleric living in the time of Sigismund of Luxemburg (1387-1473), King of Hungary and Holy Roman Emperor. Tar paid a visit to St Patrick's Purgatory in Lough Derg and wrote a medieval account of his journey in Latin, mixing legend with travelogue, real with religious and imaginary experiences (Fügedi 1974, 156-157 and Kabdebo 2001, 19).

Religion was also the background of an Irishman fleeing the troops of Oliver Cromwell's Irish campaign. Walter Lynch, Bishop of Clonfert, stayed in the northwestern Hungarian city of Győr from 1655 to 1663, and donated an icon of the Virgin Mary to the Cathedral of Győr. The icon subsequently became revered as the "Virgin that shed tears" on St Patrick's Day in 1697. Because of its miraculous attributes the Weeping Mary of Győr has been used as a destination of Roman Catholic pilgrimage by adherents of the church to this day. Religious orientation permeates seventeenth-century Hungarian chronicles too which refer to ongoing Irish events and comment upon them in terms of the chroniclers' own 
Protestant or Catholic affiliations. Therefore, these intercultural references also reflect religious divisions in Hungary at the time.

Considering the potential impact of the above mentioned contacts on Szemere I refer to István Pálffy's seminal study entitled "Hungarian Views of Ireland in the Nineteenth Century." Here Pálffy states that nineteenth-century Hungarian interest in the Irish and their country seems to have derived from the medieval or early-modern relations which, on the other hand, fit into the story of a never ceasing Hungarian interest in the Western World. But, as Pálffy continues, these early contacts were primarily determined by religious factors, therefore, they did not have a direct impact on the political, social and economic curiosity that Hungarian reformers of the nineteenth century developed in Ireland $(1987,33)$.

Nevertheless, an early-eighteenth century event already indicates the appearance of Hungarian interest in Ireland's political situation. It is connected to Prince Ferenc Rákóczi II, leader of a prolonged military campaign in 1703-11 to gain independence from the Habsburgs. Although the fight for freedom eventually failed in 1711, at the height of his success in 1707, Prince Rákóczi dethroned the House of Habsburgs in Hungary, and argued that Hungary's connection with Austria was constitutionally similar to that of Scotland and England, that Austria handled Hungary as England treated Ireland, that is, as a "conquered country" without "ever having conquered it" (qtd. in Kabdebo 2001, 21). In his extended study of Irish-Hungarian parallels Thomas Kabdebo (2001) claims that Rákóczi's argument indicated the understanding of a national parallel between the two countries, and that this understanding strengthened and deepened in the following centuries. Kabdebo supports his claim about the exact nature of what he calls "a valid national parallel" in the following words:

Historical veracity of parallels [...] does not depend on the minutiae of chronological, social or institutional or even economic details but on the similarity of situations. Parallels are drawn by active agents of the historical process who discover similar agents acting in a similar historical process. In that sense parallels are always discovered against not dissimilar backgrounds, in situations fairly akin, such as: "method of rule," dependency, "empire building," "colonizing" or "being colonized." But, perhaps, the most relevant is the correlation of contexts: emerging nationalism, nationalism in its assertive phase, [...] could bring two geographically distant countries into a valid parallel. $(2001,29)$

In fact, the tenacity of Kabdebo's conception about Hungarian-Irish national parallels has been challenged by some scholarly works, particularly on grounds of historical fact and accuracy (see e.g. O’Reilly 2003 and Pintér 2015). But I anticipate here that a sense of shared fate between Hungary and Ireland was 
relevant to a group of Szemere's potential sources that I will discuss in connection with the nineteenth century.

As an answer to my question about the place of Szemere's journey in the tradition of Irish-Hungarian relations I conclude that it obviously fits into a long line of Hungarian interest in the Emerald Island and that Szemere's account of Ireland belongs to a centuries-old discourse generated by moments of direct or indirect contact between the two peoples. At the same time, I share Pálffy's view and argue that whereas the above mentioned early sources might have contributed to the arousal of Szemere's curiosity about Ireland, they did not really inform his representation of the country in his Utazás külföldön.

\section{Szemere and Other Hungarian Travellers in Ireland in the Age of Reforms}

It is unlikely that mere tradition had been adequate motivation for Szemere to take a detour to Ireland and extend his already long and tiring journey. By August 1837, the last phase of his travels in Europe, he must have been very exhausted both physically and mentally. Throughout the one and a half year-long trip he had to rely on a very tight budget, and a persistent lack of money caused him to struggle continuously with privation and even with hunger. This raises the question: what urged Szemere to take further trouble and see Ireland with his own eyes?

Some insight into the underlying processes of Hungary's Reform Age reveals that a most effective instrument for Young Hungarians to widen and deepen their understanding of the world, and to find ways of improving conditions at home was to take "study trips" abroad. Szemere's journey belonged to this outmigration of Hungarian reformists to gain first-hand experience in the modernized countries of the Western World.

Furthermore, Szemere's trip to and his subsequently published account of Ireland were not exceptional in mid-nineteenth century Hungary either. In the nineteenth century we need to recognize a remarkable growth of mutual and genuine interest by certain Hungarian and Irish public figures in the events of their countries, which then gained expression in a series of published texts in both countries.

On the Irish side, Hungary's Age of Reforms, particularly the success of the language movement in securing for Hungarian the status of an official, modern printed language, then the rise and demise of the Hungarian War of Independence evoked high appreciation as well as deep compassion in certain leaders of nationalist Ireland. Irish texts making such references to contemporaneous Hungarian events include Young Irelander Thomas Davis's "Our National 
Language” (1846), Thomas Darcy McGee's narrative of the failed Young Ireland Uprising of 1848 (1914) and John Mitchell’s “Jail Journal” (1913) (see Pintér 2015).

On the Hungarian side, a group of these texts is pertinent to the above mentioned outflow of Hungarian reformists to the Western World. In what follows I am going to explore how documented Hungarian visits to Ireland in the first half of the nineteenth century inspired and influenced Szemere to take the trip and publish his own description of Ireland.

In the early 1830s Sándor Bölöni Farkas accompanied Baron Ferenc Béldy on a journey to North America, which included a detour to Ireland. As a part of his subsequently published travelogue Utazás Észak-Amerikában or A Tour in North America (1834), Bölöni summed up his impressions of the Irish island. Ferenc Pulszky went to Ireland in 1833-34 and published his travelogue about the country under the title Úti vázlatok or Sketches of a Journey from 1836. As both of these works had left print before Szemere set out on his journey, he must have known them. In fact, Szemere's distress and pain caused by the sight of misery in Dublin echoes Bölöni's compassionate tone in the remark: "We found Dublin amid great vicissitudes and unevenness. There are a lof of things in Ireland that make the traveller feel dispirited" (qtd. in Csorba 1944, 43).

Regarding the emotional side of these travelogues István Pálffy says that although earlier Reform-Age Hungarian visitors had also been shocked by the poverty of the Irish, it was Szemere who found the most appropriate style to express his astonishment at what he saw in that country: "It was then that first in my life I realized that this earth is the vale of tears. What this nation [i.e. the Irish] wants is a new Saviour" (qtd. in Pálffy 1987, 35). Reflecting upon this quote Pálffy points out that the style of Szemere's representation of Ireland was greatly determined by his individual sensitivity to human suffering and by the anxiety he felt over his own nation's grievances $(1987,35)$.

A comparison of Szemere's account of Ireland to Ferenc Pulszky's travelogue shows that in his own description Szemere fundamentally addresses the same issues as Pulszky, and presents them from very similar angles. For instance, both Pulszky and Szemere write about the economic backwardness of the rural Irish, the growing strength of political agitation in Ireland and both are shocked by the sharp contrasts in the living circumstances of Dublin's population. This suggests Pulszky's influence on Szemere, but it also raises the possibility of both authors relying on the same outer sources - which is a topic I will return to later in this study.

From the above we can discern that there is a clear impact on Szemere of those Hungarian travellers who had just preceded him in visiting Ireland and in publishing accounts of the country. By all probability, these texts spurred Szemere to extend his journey to Ireland, preconditioned him for what to expect there, and subsequently helped him frame and thematize his own representation of the country. Szemere's tone and style obviously harmonize with the romantic ethos 
of the age and share in the deep sympathy that his fellow Hungarian travellers felt about the Irish poor. On the other hand, they express in words the emotional responses that the sight of human suffering engendered in Szemere as a sensitive individual and as a responsible reformist person.

Szemere's account can be considered as an integral part of Hungary's ReformAge discourse on Ireland also becasue it functioned as a catalyst for further texts on the same topic. Novelist and highly reputed politician Baron József Eötvös's essay entitled "Szegénység Irlandban” or "Poverty in Ireland” (1840) greatly influenced Hungarian public thinking about Ireland. As we know, in this case it was Eötvös who relied upon the experiences of Szemere and Pulszky, both being friends to him (Kabdebo 2001). Like Szemere, Eötvös too, expresses deep sympathy towards the conditions of the Irish. But Eötvös's work is not a romantic travelogue. It is an insightful social study concerned with Ireland's colonial history and the ways prolonged dependence on Britain had caused economic hopelessness, basic poverty and human misery by the nineteenth century (Eötvös 1902, 38-108).

\section{Szemere and Irish National Politics}

In 1842 Lőrinc Tóth and István Gorove, two young ambitious politicians visited Ireland, and they published their accounts in 1844. Tóth and Gorove also belonged to the group of reformist travellers in Ireland, but unlike Szemere, they were primarily attracted to the country by their interest in politics. As their writings demonstrate they were truly impressed by the charismatic personality and national mass movements of Daniel O'Connell, "Liberator" of Catholic Ireland (Csorba 1944).

In fact, Tóth and Gorove's politically motivated visit to Ireland fits in with the rise of a hightened Hungarian interest in Irish politics in the Age of Reforms. Pálffy associates this phenomenon with the emergence of a sense of companionship in fates between the Irish and the Hungarians (1987, 33). Whereas Kabdebo (2001) originates the idea of an Irish-Hungarian parallel in Rákóczi's previously cited proclamation, Pálffy points out that common fate was first sensed by reformist Hungarians who understood how much nineteenth-century Ireland's relations with Great Britain resembled those of Hungary with the Habsburg Empire. On the Hungarian side this sense of shared fate was consciously cultivated by the first Hungarian periodicals, whose publication was facilitated by the development of Hungarian as a printed language in the first half of the nineteenth century. These papers, including Hasznos Mulatságok or Useful Passtimes (1831), Rajzolatok or Sketches (1835), Társalkodó or Companion (1836) and Atheneum (1837), carried articles on Ireland thus introducing Hungarian readers to Irish realities 
and opening their eyes to political developments in this faraway island country (Kókay 1979, 458, 509 and Pálffy 1987, 33).

Probably the most effective instrument to generate political excitement in Hungary about Irish affairs was Lajos Kossuth's Pesti Hírlap or Pest News. Radical reformist and future leader of Hungary's Revolution of 1848 Lajos Kossuth showed keen interest in the achievements of Irish constitutional nationalist Daniel O'Connell, and the 1843 issues of his Pesti Hírlap include multiple references to the Liberator's Repeal Association (Kókay 1979, 675). As indicated by its name the Repeal Movement attempted at the withdrawal of the existing union between Great Britain and Ireland by replacing Westminster's direct control in Ireland with a system of Irish self-government. O'Connell's campaign attracted attention in Hungary in the early 1840s because some Hungarian reformists saw in it a model political programme for their country to loosen the Habsburg bondage.

We know that O'Connell's insistently peaceful movement failed when it was faced with uncompromising British unionism and imperialism. Besides the disastrous consequences of the Irish Famine of 1845-49, this also contributed to the radicalization of Irish nationalism in the decades to come. A relevant question, which exceeds the limits of this study, is whether the failure of O'Connell's peaceful policies enhanced Kossuth and his circle's urge to press for more radical ways and more ambitious visions concerning Hungary's constitutional status.

However, Szemere's visit to Ireland had preceded this climax; and it would be a misunderstanding to put Szemere under one roof with radical Hungarians showing enthusiasm for Irish national politics (see Kabdebo 2001). It is true that, particularly towards the later 1840s, Szemere got intensely engaged with Hungary's independence politics. Furthermore, at the "height" of his political career he replaced Kossuth as Prime Minister of Hungary's first, temporary responsible government. But at the time of his visit to Ireland Szemere occupied a relatively moderate platform of Reform-Age politics, which positioned him closer to the Centralist Party of József Eötvös, Zsigmond Kemény, László Szalay and Antal Csengery than to the more radical circle of Lajos Kosuth. Although later on there were shifts in Szemere's political loyalty to Kossuth - during the Independence War he sided with him, then, in emigration he turned against him - in the late 1830s Szemere's description did not anticipate the admiration that Kossuth and likeminded Hungarian radicals were to express for Irish constitutional nationalism.

The following quote from his account proves that in 1836-37 Szemere was well aware of the goings-on of Irish politics. However, it also reveals that Szemere refrained from expressing any excitement, let alone enthusiasm towards Irish national politics: "Parliamentary elections are going on and O'Connell is one of the candidates [...]. That party should be supported which finds remedy for this suffering people. [...] While parties are competing, people are bleeding, torn between two edges" $(1983,358)$. 
What Szemere says here about O’Connell's political campaign resembles the attitude of a sceptical outsider; and he does not make any direct reference to Ireland sharing a political fate with Hungary. On the other hand, his sympathy with the Irish people as victims of rivalling political parties provides further evidence that his responses to Irish realities were conditioned by his own and his nation's hardships. Reckless party electioneering, irresponsive to the actual needs and sufferings of the population, was not alien to that time Hungary either. Experiencing the same phenomenon in Ireland probably filled Szemere with dismay and apathy.

A different reading of Szemere's remoteness to Irish politics leads to a thoughtprovoking finding: it echoes the observation of a German traveller. The translated and edited version of the German report came out in the Hungarian periodical Társalkodó in 1836 under the title "Irland júliusban. Töredékek egy német utazó jegyzeteiből” or "Ireland in July. Excerpts from the Notes of a German Traveller." One of Szemere's phrases is, in fact, a nearly verbatim quote from this text presenting Ireland as "a country torn apart by political parties” (Társalkodó 1836, 305-307).

This leads to my proposition that although Szemere went to Ireland as a Hungarian reformist and his perspective and mode of thinking were moulded by the ethos of the Hungarian Age of Reforms, his account of the country reflects the impact of foreign sources. The search for Szemere's foreign sources actually intersects the search for his real motive to visit Ireland.

\section{Szemere and his German "Intermediary"}

As is revealed by his account, in Ireland Szemere was mainly concerned with the condition of the poor. The following quote demonstrates that he primarily went to Ireland to directly observe a phenomenon that he had been aware of before his journey: "[I came to Ireland to see] whether the deep destitution, which had become known all over the world, is a reality. [...] I came as a patriot and an altruist, with curiosity and an anxiously beating heart to see a sick country" $(1983,353)$.

With respect to Szemere's anticipation of seeing distressing poverty in Ireland I quote István Széchenyi, to many the greatest Hungarian reformer. In his Döblingi Iratok or Döbling Papers of 1831 Széchenyi states that Irish poverty had become a European issue. Széchenyi's observation relates to German historian Friedrich Ludwig Georg von Raumer's study of conditions in Ireland in 1833, which made Europe conscious of the extent and severity of poverty on the Emerald Island (qtd. in Csorba 1944, 35-36).

In fact, interest in Irish poverty tapped into a solidifying understanding by European governments and public figures of various backgrounds that pauperism was the root cause of the most troubling social phenomena of the age, including 
public insecurity, endemic crime, lack of public sanitation and health, the spread of fatal diseases, etc. Thus, poverty became a deeply studied and widely publicized issue all across Europe. As evidenced by the following quote from Hasznos Mulatságok it also reached the surfaces of Hungarian periodicals: "An Englishman has estimated the number of paupers in Europe at 18,900,000" (1831. I, 80). This suggests that Szemere's - and previously Bölöni's and Pulszky's curiosity in pauperism in general, and Irish pauperism in particular had been awakened by the wider context of European attention and discourse, to which they had access through the Hungarian printed media.

This is pertinent to Pálffy's argument referring to the role of "intermediaries" (1987, 34-35). These intermediaries or "agents of Europeanization" provided virtual links for acquainting geographically distant cultures, like the Irish and the Hungarians, with one another. The Hungarian periodicals of the 1830s were important relays in the flow of information: they took over, translated, edited and published numerous Austro-German reports originally circulated in AustroGerman printed newspapers. The reports - Pálffy adds - prompted Hungarians to set out to discover Ireland in person, writing afterwards travelogues which count as the first genuine Hungarian reports on the Irish and their land.

I propose that these intermediaries were not only prompts for Szemere to visit Ireland but also important sources for his subsequently published account of the trip. I found my proposition on the fact that Szemere was a regular reader of these reports before, during and after his journey, and on the findings of my research into Szemere's foreign sources. As a proof of this first I am going to provide a brief topic by topic comparison of the account of Szemere and of the German traveller whose opinion on Irish politics I have already shown to impact Szemere.

For instance, Szemere's presentation of a two-faced Dublin likened to Rome as I quote at the beginning of this paper - reveals striking resemblance with the perspective of the German report. The German author draws a parallel between Dublin and another Italian metropolis, namely Naples, with regard to a sharp contrast between the highest luxury and the deepest human misery co-existing in either city. He writes that affluence and privation present themselves in the most distorted contrast "in this unhappy country." The Rotunda of Dublin gives shelter to "wretched, maimed, and paralysed people" but it also provides space for green terraces decorated with "Irish women, the flowers of Ireland, who emulate the English gentle ladies in beauty and pleasant manners." The German author underlines that a shocking gap in living standards can be observed not just in Dublin or Naples but in any other metropolis of the world, and that this phenomenon is known and discussed widely (Társalkodó 1836, 305-307). It is relevant to note that Ferenc Pulszky in his Úti vázlatok also depicts Dublin in terms of a parallel with Naples (Csorba 1944, 44). This strengthens my earlier supposition that Pulszky and Szemere shared some identical outer sources. 
It appears that both of them relied on the German report under discussion, indicating that Szemere's use of intermediaries for his own travelogue was not exceptional in Hungary of the time.

Another topic presented in remarkably similar terms by both Szemere and the German traveller is the physical appearance of Dublin's paupers and the related trade in second-hand clothes - seen as a sign of Britain's shameful exploitation of the Irish. As his account reveals Szemere is truly appalled by the distressing look of half-naked children in dirty rags (1983, 354-355). He sadly comments that the worn-out, miserable clothes are sold in certain Dublin shops, where they are poured from all over Great Britain in compensation for the food that Britain snatches from under the starving mouths of the Irish poor. Here Szemere elaborates on the following remark of the German traveller: "The trade in worn-out, ragged clothes forms an unusual branch of commercial activity that is conducted to the Irish regions by the English and the Scots" (1983, 305-307).

With respect to the general disposition of the people, Szemere claims that the Irish are joyful, gentle and talkative, showing nearly nothing of the English or Scottish reserve and bias towards foreigners: "In London and Edinburgh the person whom the locals recognize as a stranger will experience a lot of inconveniences, and in order to avoid involvement in a street fight, he often needs to tolerate minor vexations. But in Dublin the visitor can roam the streets peacefully - not disturbed by a single look of reprehension" (1983, 357-358). Szemere furthers the comparison of the Irish and English national characters by recognizing the deep prejudices that the English hold towards the Irish. He laments that England is unaware of the true nature and the real needs of the Irish people, and that this derives from the traditional English fear and alienation regarding "Papists." $\mathrm{He}$ adds, "the traveller is sincerely puzzled by the level of blinded hatred that the English, an otherwise civilized and free-thinking nation, are capable of nurturing towards their oppressed compatriots" (1983, 357-358).

Whereas Szemere's tone is saturated with compassion towards the Irish, his judgement of the English is fairly negative, expressing a mixture of disillusionment and dislike. In fact, Szemere's attitude significantly deviates from the respect and admiration that Hungarian reformists had felt towards England and the English in the 1820s. Hungary's Anglomania was acknowledged by foreign visitors, including English traveller and writer Catherine Gore, who writes the following in her Hungarian Tales: "The Hungarian nation, ancient and picturesque [...] appears to be at present little known, and perhaps still less cared for in England. Our indifference is significantly ungrateful; for there is scarcely a European country in which the Anglomania rages more fiercely that in that slighted land" $(1829,9)$.

In search of an explanation for Szemere's "untraditional" criticism of the English I identify two factors that could qualify his perspective. Firstly, the direct experiences that he gained during his journey must have had a transforming and, 
undoubtedly, refreshing effect on his image and understanding of the British Isles. Secondly, a comparison of his view with his German intermediary's shows that Szemere saw the English and the Irish also through German and not just through traditional Hungarian lens. Although Szemere's voice signifies much deeper emotional involvement with the Irish, his judgement of the English is fundamentally the same as the German traveller's, who writes:

Certainly, one cannot travel anywhere in greater security than in this badly reputed country. The inhabitants of Ireland are honest, open-hearted, talkative and communicative. [... Nevertheless,] England maintains relentless enmity towards the Irish, which, in fact, is fed by continuous fear. Therefore, the Englishman who is travelling in Ireland is constantly haunted by the nightmare of being robbed or stabbed in the neck. (Társalkodó 1836, 305-307)

The study of these common topics and modes of discussion has proven to me that this German report was a primary source for Szemere to create his own representation of Ireland. It has also become evident that the Társalkodó, a periodical on science, art and craft, which edited and published the German account in Hungarian in 1836, was an important instrument in forwarding knowledge and information to Szemere about Ireland. Yet, this still leaves the ground open for Szemere's source of fact and detail and for his analysis of the causes of Irish poverty. The most likely candidate here is an English intermediary: William Cobbett.

\section{Szemere and His English "Intermediary," William Cobbett}

William Cobbett (1763-1835) was an English patriot, landowner, radical journalist and reform campaigner. In 1834, he visited Ireland and wrote letters to Charles Marshall, his farmhand in Surrey. Cobbett's "Letters on Ireland" were promptly published by the English journal, Political Register. In just a few months they came out in the Wiener Courier in German, and then the Hungarian periodical Társalkodó published an edited version of Cobbett's letters in Hungarian, entitled “A' szegények Irlandban” or "The Poor in Ireland” (Társalkodó 1834, 385-386, cf. Pálffy 1987, 35). As their subsequently published accounts demonstrate Cobbett's report had a deep influence on more Hungarian reformers who later visited Ireland, among them Pulszky, Baron József Eötvös, as well as the focus of this study, Szemere.

In the introduction of this paper I have noted that Szemere's description includes some fact-based observations which presuppose a deeper and more thorough 
study of conditions in Ireland, and which his three-day visit in Dublin did not possibly allow him to accomplish. Relying on my preliminary investigation I argue that Cobbett's altogether ten letters on Ireland were the most important source of fact and detail for Szemere, and that Cobbett also informed Szemere's analysis of the causes of poverty and economic backwardness in Ireland. I will support my argument with presenting some of the topics where Szemere's reliance on Cobbett as his English intermediary appears to be the most evident.

Szemere's description of Dublin evokes parts of Cobbett's Letters Number I and II, dated on 27 September and 4 October respectively. For instance, his heartstirring snapshot of a Dublin free kitchen which gives food to some three thousand paupers daily (1983, 356-357) echoes Cobbett's report of his visits to a Dublin "mendicity” or "beggary." Here Cobbett was shown around by "the gentlemen, who have the management of the place" and where food is prepared and distributed for "about three thousand wretched people" twice a day. Cobbett remarks that if these people were not thus fed with some potatoes "mashed as you mash for your hogs, [...] they must either die, or thieve or rob" $(1984,43-44,59)$.

Elsewhere, Szemere makes mention of a public school in Dublin where hundreds of miserable children, an equal number of boys and girls, are taught and fed (1983, 356-357). This relates to Cobbett's following description: "There were about a hundred little girls in a school, and about as many boys in another; neither had shoes or stockings, and the boys had no shirts. Their faces were pale, the whole hundred not having so much red as your little round-faced chap that was set to keep the birds away from the cabbage seed in Dodman's field" (1984, 59-60).

As the above and the next passages show the scarecrow simile is a recurring motif in Cobbett's letters: "In another place [of Dublin] I saw a great crowd of women sitting and doing nothing, each with a baby in her arms. [...] It was one mass of rags [...] far worse than any that you ever saw tied round a stake to frighten the birds from our wheat and our peas" $(1984,60)$. The fact that Szemere uses the scarecrow-simile indicates that, besides topic and detail, he was also impressed by some of Cobbett's visual images. About the second-hand clothes shops Szemere writes the following: "These low holes of shops are decked with ragged clothes all over. Some of the rags are hung on poles and stuck out of the buildings' first or second floors as shop signs. Should I see them on roofs or in meadows I would think that they were put up to frighten away birds" $(1983,354)$.

Although the conditions of his journey must have prevented Szemere from a close scrutiny of the Irish countryside, he provides an accurate description of a rural cabin and the distressing living conditions of its inhabitants. He writes that a dwelling cabin only covers twenty square feet, its walls are made of mud and its floor is of the earth where it stands. It does not have an attic, and its roof is just a smoky top, which is made of mud and weed, and which has no chimney at all. Its window is not more than a foot-long hole and a couple of planks are 
nailed together for a door $(1983,360)$. In fact, Szemere could gain these pieces of information from various sources, but the resemblance of his description to Cobbett's Letter III, dated in Kilkenny on 1 October 1834 is worth considering:

The places which I call houses were in general from ten to twelve feet square; the walls made of rough stone and mud [...]; no ceiling; rough rafters covered over with rotten black thatch; in some a glass window [...] about a foot long, and four or five inches wide; the floor nothing but the bare earth; no chimney, but, a hole at one end of the roof to let out the smoke [...]. $(1984,82)$

Even more revealing of Cobbett being a source for Szemere is the remarkable overlap between Szemere's discussion of the causes of economic backwardness and poverty in Ireland and the analysis that Cobbett provides about the same topic in his Letter IV, dated in County Waterford on 6 October. The causes that both authors identify include the subdivision of land into tiny plots, the worst kind of potato being the staple food for the rural poor, low day wages for agricultural labour, a lack of job security, Ireland's heavy dependence on Britain, reckless spending by absentee landlords, and the payment of heavy tithes to the official Anglican Church.

Nevertheless, Szemere's use of Cobbett's report is not uncritical but conditioned by his own views and background as a Hungarian reformist. This is evidenced by the two authors' diverging ideas concerning the path of proper economic development for Ireland. Like most of his reformist compatriots Szemere was greatly concerned with Hungary's obsolete economic structure, a solidified feudal system of land tenure and a serious lack of capitalist investment and initiative. All this Szemere saw at the root of rural poverty and underdevelopment. It follows that in his brief discussion of the causes of economic backwardness and pauperism in Ireland he primarily accuses the absence of English capital and industry. At the time of Cobbett's visit to Ireland, England was already on its way to liberal economy. But, as a Tory opponent of capitalist change Cobbett was concerned with the destruction of rural, self-sustaining communities by Britain's transition to industrial modernity. Therefore, he attributes the agricultural crisis in England and in Ireland, and in the latter the shocking contrast between agricultural abundance and desperate poverty to the change to industrial modernity, facilitated by the combined influences of Malthusianism, free trade and debt finance, and in Ireland to absenteeism and agrarian, export orientated capitalism.

In his study of Cobbett's Irish writings Alex Benchimol (2013) points out that according to some scholarly opinion Cobbett had foreseen the Great Famine, which was to devastate Ireland ten years later. Concluding my discussion of Cobbett's direct impact on Szemere I quote Szemere's farewell, which sadly echoes Cobbett's alleged prognosis of Ireland's impending humanistic crisis: "I envisioned Ireland 
as a huge burial mound, enfolded by the darkness of a mourning night, and I looked upon my journey back as a return from a graveyard” $(1983,365)$.

\section{Conclusions}

In this study I have examined Szemere's account of Ireland in his travelogue Utazás külföldön from a special perspective. Noting a discrepancy between his fleeting stay in Dublin and the depth and detail of his description of Ireland I have hypothesized that - besides his first hand experiences and impressions some outer sources have significantly impacted Szemere's image of Ireland.

My investigation of Szemere's potential sources has yielded the following results. Szemere's account of Ireland belongs to a centuries-old discourse generated by moments of direct and indirect contact between Hungary and Ireland. But, whereas the medieval and early-modern Hungarian sources probably increased Szemere's curiosity about Ireland, they did not directly inform his representation of the country.

Furthermore, Szemere's account forms an integral part of Hungary's ReformAge discourse on Ireland. There is a clear impact on Szemere of those Hungarian travellers who had just preceded him in visiting Ireland and in publishing accounts. Szemere knew these texts, they motivated him to take the journey, and informed afterwards his own description. But, in terms of detail and insight, it is not the earlier Reform-Age writings that count as direct sources for Szemere but contemporaneous texts of foreign origin. As I have explored and demonstrated, the European sources that most heavily impacted Szemere's representation include the report of a German traveller and Cobbett's letters on Ireland, from 1834. Both these sources were made available to Szemere in edited Hungarian version by the Reform-Age periodicals Társalkodó and Hasznos Mulatságok.

My study has revealed that Szemere's journey and description were not inspired by enthusiasm for Ireland's national politics or a sense of shared political fate between Hungary and Ireland (cf. Kabdebo 2001 and Pálffy 1987). In Ireland Szemere was primarily concerned with the appalling poverty, the shocking social and economic contrasts and the causes of all this. Also, Szemere's awareness and understanding of these phenomena tapped into the wider context of European discussion going on about Ireland and pauperism in Ireland.

Consequently, the genuineness of Szemere's account lies in the mode of discussion that merges information from Western European sources with his locally conditioned personal reflections, thus creating a unique representation of Ireland. Another merit of Szemere's work is that it highlights a specific aspect of the flow of ideas from Western Europe to Hungary in Hungary's Age of Reforms. Therefore, I propose further research into the interaction of Hungarian and European discourse concerned with Ireland in the nineteenth century. 


\section{Works Cited}

Benchimol, Alex. 2013. "Foreseeing the Famine?: William Cobbett's Irish Writings.” In Romantic Ireland: From Tone to Gonne, eds. Paddy Lyons et al., 10-20. Newcastle upon Tyne: Cambridge Scholars Publishing.

Bölöni Farkas, Sándor. 1834. Utazás Észak-Amerikában. [A Tour in North America.] Kolozsvár.

Cobbett, William. 1984. Cobbett in Ireland: A Warning to England. Ed. Denis Knight. London: Lawrence and Wishart.

Csorba, András. 1944. Magyar-ír kapcsolatok 1867-ig. [Hungarian-Irish Relations until 1867.] Debrecen: Tisza István Tudományegyetem.

Eötvös, József. 1902 [1840]. Tanulmányok. [Essays.] Budapest: Révai Testvérek.

Fügedi, Erik. 1974. Uram, királyom ... A XV. századi Magyarország hatalmasai. [My Lord, My King... The Mighty of Hungary in the $15^{\text {th }}$ Century.] Budapest: Gondolat.

Gore, Catherine. 1829. Hungarian Tales. London: Saunders and Orley, ConduitStreet. https://ia802302.us.archive.org/25/items/hungariantales01gore (Last accessed 12 February 2014)

Hasznos Mulatságok. A Hazai s Külföldi Tudósításokhoz Toldalékul, vols. 1-2. [Useful Passtimes. Additions to Reports from Home and Abroad.] Pest. 1831.

Kabdebo, Thomas. 2001. Ireland and Hungary. A Study in Parallels. Dublin: Four Courts Press.

Kókay, György, ed. 1979. A magyar sajtó története I, 1705-1848. [The History of the Hungarian Press I, 1705-1848.] Budapest: Akadémiai.

O’Reilly, William 2003. "Review of Ireland and Hungary: A Study in Parallels, by Thomas Kabdebo.” Slavonic \& East European Review vol. 81 no. 2: 357-359. http://www.jstor.org/stable/4213716 (Last accessed 2 August 2012)

Pálffy, István. 1987. "Hungarian Views of Ireland in the Nineteenth Century." In Literary Interrelations, vol. 1, eds. Wolfgang Zach and Heinz Kosok, 33-37. Tübingen: Narr Verlag.

Pintér, Márta. 2012. "Hungarian-Irish Parallels: National Language in $19^{\text {th }}$-Century Ireland." Bulletin of the Transilvania University of Brasov vol. 5 no. 54: 25-30. Pintér, Márta. 2013. "Hungarian-Irish Parallels: The Elevation of Mid-19 ${ }^{\text {th }}$ Century Nationalist Ireland through Irish-Hungarian Parallels by Young Irelanders.” ELOPE English Language Overseas Perspectives and Enquiries vol. 10 no. 1 (Spring): 63-70.

Pintér, Márta. 2015. "Hungarian-Irish National Parallels as Ideological Constructions.” TOPOS Journal of Space and Humanities vol. 4 no. 1 (Spring): 99-108. 
Pulszky, Ferenc. 1914 [1836]. Úti vázlatok. [Sketches of a Journey.] Budapest. Szemere, Bertalan. 1983. Utazás külföldön. [A Journey Abroad.] Budapest: Helikon.

Társalkodó. Tudományos Múvészeti s Mesterségi tekintetben. [Companion. On Science, Art and Craft.] Pest. 3 December 1834 and 24 September 1836. 